\title{
Labour Dispute Resolution Process and Its Impact on the Rights of Low-Skilled Temporary Foreign Workers in the Absence of a Labour Court in Saudi Legal System: A Critique
}

\author{
Abdullah Almutairi ${ }^{1}$ \\ ${ }^{1}$ Brunel Law School, Brunel University London, United Kingdom \\ Correspondence: Abdullah Almutairi, Brunel Law School, Brunel University London, United Kingdom. E-mail: \\ abdullah.almutairi22@hotmail.com
}

Received: May 7, 2017

Accepted: July 18, $2017 \quad$ Online Published: February 28, 2018

doi:10.5539/ilr.v7n1p199

URL: https://doi.org/10.5539/ilr.v7n1p199

\begin{abstract}
This article deals with the issues linked to the process of resolving labour disputes and their impact on the rights of low-skilled Temporary Foreign Workers. In doing so, the article intends to provide an overview of the development of the legal system in Saudi Arabia in an effort to provide a critical review of the main authorities influencing the Saudi legal structure and highlight the current reforms of the judicial system. For the purpose of this study, this paper examines the judicial and quasi-judicial bodies to understand the issue linked to the process of resolving labour disputes and its impact on the rights of TFWs. Due to the absence of a labour court from the existing judicial structure, it is essential to consider the regulations for litigation before the commissions for the settlement of labour disputes issued by the Saudi Council of Ministers. This article highlights the key labour cases that are interrelated with employment contracts and residency (Iqama) regulations in order to review the jurisdiction of the commissions. Finally, the paper provides a suggestion to resolve the problems of labour dispute resolution process with special reference to TFWs cases.
\end{abstract}

Keywords: labour dispute, residency (Iqama), sponsorship (Kafala) system, quasi-judicial, modernist, traditionalist, labour law

\section{Introduction}

Since 1970, as a result of the economic boom, the Saudi legal system has been developed and a number of laws have been enacted, including administrative and commercial laws, and laws in the criminal and labour domains. Such laws are in line with the in-depth development plans experienced by the country, ${ }^{1}$ including many laws and regulations enacted with the aim of protecting workers' rights. Temporary foreign workers' (TFW) rights are covered by the Labour Law (2005, amended in 2015) which defines the rights and responsibilities of labourers and employers; ${ }^{2}$ the Commissions for the Settlement of Labour Disputes which deals with adjudicating disputes between workers and employers; ${ }^{3}$ and the Residence (iqama) Regulations (1952) which aim to provide better management of the influx of temporary contract labour. ${ }^{4}$

However, the Saudi legal system's development has been influenced by both modernist and traditionalist approaches. In fact, the tension between modernist and traditionalist approaches has impacted the legal structure of Saudi Arabia. ${ }^{5}$ Negative (traditionalist) approaches to enacted law such as Saudi labour law (hereinafter the SLL) and other rules and regulations related to the settlement of labour disputes caused the government to

\footnotetext{
${ }^{1}$ See Ayoub Al-Jarbou, 'The Role of Traditionalists and Modernists on the Development of the Saudi Legal System' (2007) 21(3) Arab Law Quarterly 191, 201.

${ }^{2}$ See Labour Law, issued by Royal Decree No. M/51 (27 September 2005), amended by Royal Decree No. M/24 date 12/05/1434H (24 March 2013) and amended by Royal Decree No. M/64 05/06/1436H (24 October 2015). See also the Implementing Regulations of Saudi Labour Law (6 April 2016) issued in accordance with art 243 of Labour Law.

${ }^{3}$ Commissions for the Settlement of Labour Disputes established in accordance to Art 212 of Labour Law, issued by Royal Decree No. M/51 (27 September 2005), and amended by Royal Decree No. M/24 date 12/05/1434H (24 March 2013) and amended by Royal Decree No. M/64 05/06/1436H (24 October 2015).

${ }^{4}$ Saudi Residence Regulations, Royal Decree No. 17/2/25/1337 (4 June 1952).

${ }^{5}$ See Al-Jarbou (n 1) 191-192.
} 
transfer such cases to administrative committees under the executive authority of the Ministry of labour (hereinafter MoL), which are not recognised by the Basic Law of Governance as a part of judicial authority. ${ }^{6}$

Such committees have quasi-judicial functions and their decisions have legal implications which are questionable due to the absence of independence and impartiality as they fall under the jurisdiction of MoL (executive authority). ${ }^{7}$ Thus, examining the effectiveness of these administrative committees shows several important legal deficiencies that could have a negative impact on the settlement of labour disputes, especially for TFWs.

Despite a number of regulations and laws governing employment relationships and protecting the TFWs, many human rights violations that TFWs experience in the Saudi labour market (hereinafter SLM) are interrelated with employment contracts and residency regulations in such a way that the existing legal structure fails to address TFW issues sufficiently. Therefore, it is essential to consider the regulations for litigation before the commissions for the settlement of labour disputes (hereinafter the commissions) issued by the Council of Ministers. In this regard, this article highlights the key labour cases related to residency regulations (e.g. confiscating labour passports, runaway huroob workers and transfer the kafala) in order to review the jurisdiction of the commissions. ${ }^{8}$

The aim of this discussion is to guide the understanding of issues linked to the process of resolving labour disputes and its impact on the rights of TFWs. This article intends to provide an overview of the development of the Saudi legal system in an effort to provide a critical review of the main authorities influencing the legal structure and highlight the current reforms of the judicial system. Due to the absence of a labour court from the existing judicial structure, this study suggests tracing the impact of modernist (legal professionals) and traditionalist (religious scholars) approaches to the legislative process, judicial system and enacted law such as the Saudi labour law (hereinafter SLL). This article concluded by providing a suggestion to resolve the problems of labour dispute resolution process and eliminates the confusion in the Saudi legal system with special reference to TFWs cases.

\section{The Development of the Legal System in KSA}

KSA is recognised as one of the most conventional Islamic legal systems in the world. ${ }^{9}$ KSA interprets the Sharia narrowly, with every Muslim being required to adhere to the binding power and influence of the Sharia. Importantly, the Sharia is not only concerned with governing religious devotion and reasoning, but is applicable across all domains of life, providing a foundation for all Muslims' lives. ${ }^{10}$ Accordingly, the country has all of its economic, political and social development efforts centred on Islamic principles, with adherence to Sharia as its governing code. Notably, the Sharia has long been recognised as the key source of legal requirements, and hence is recognised as the national law and the public policy of KSA. ${ }^{11}$

As stated above, the Saudi legal system's development has been influenced by both modernist and traditionalist approaches. ${ }^{12}$ The Islamic scholars and jurists $(\text { ulama })^{13}$ predominantly represent the traditionalist approach. The traditionalist is deeply embedded in KSA's history, with its origins in the $18^{\text {th }}$ century Wahhabi movement, established by Shaikh Muhammad Ibn Abd al-Wahhab in 1745. Since that time, all Saudi rulers have derived the legitimacy of their rule and their conquests from the purification of Islamic creed that has derived from innovations and perversions of the original message of Islam. ${ }^{14}$

In contrast, a modernist approach is recognised as predominantly endorsed by members of educated elites, legal

\footnotetext{
${ }^{6}$ Usa International Business Publications, Saudi Arabia Company Laws and Regulations Handbook (Int'1 Business Pubns USA 2008) 59. See also Al-Jarbou (n 1) 224; and Basic Law of Governance, Royal Order No. A/91 27 (1 March 1992) Article 46: "The Judiciary is an independent authority. The decisions of judges shall not be subject to any authority other than the authority of the Islamic Sharia."

${ }^{7}$ Joseph A Kechichian, Legal and Political Reforms in Sa 'udi Arabia (1st edn, Routledge 2013) 29.

${ }^{8}$ The term Kafala is referred to the sponsorship system governing and regulating TFWs employment in Saudi labour market. The term Huroob is referred to run away or absent from the work

${ }^{9}$ Frank E Vogel, Islamic Law and Legal System (Brill 2000) xv.

${ }^{10}$ Janet AW Dray, 'International Conflicts in Child Custody: United States v. Saudi Arabia' (1987) 9 International and Comparative Law Journal 413,414

${ }^{11}$ Fahad Mohammed Al-Majed, A Conceptual Legal Framework for Reforming Saudi Corporate Governance (Lap Lambert Academic Publishing 2014) 201.

${ }^{12}$ Al-Jarbou (1) 191, 192.

${ }^{13}$ The word ulama is the plural of the word alim.

${ }^{14}$ Al-Jarbou (n 1) 192.
} 
professionals and technocrats, such as law professors and lawyers. ${ }^{15}$ The majority of such intellectuals complete their education in Western countries and play a pivotal role in the country's development and growth, including attempting to develop the legal system. The perspective adopted by a modernist approach is centred on seeking to gain advantage from Western development, including in the domain of the legal system. Modernists support the idea of the codification of all elements of the legal structure, which spans all domains of everyday life. ${ }^{16}$

It is often argued that the legal system in the country, as well as the nature and the role of the law in KSA society, are sound examples of the interaction between Saudi tribal structure, traditional Islam and modern law. ${ }^{17}$ The general principles upon which KSA was built are recognised as clearly stemming from the Basic Law of Governance, $1992 .{ }^{18}$ For example, Article 1 clearly recognises the central tenets of the KSA, and has not shifted away from the original principles detailed by King Abdul Aziz upon the formation of the united Saudi Arabia in 1932. As stated in Article 1: "The Kingdom of Saudi Arabia is an Arab and Islamic Sovereign State ... and its constitution is the Qur'an and the Sunnah." "Article two declares: "The citizens shall acknowledge the rule of the King according to the Book of God and the Sunnah of His Apostle.,"20

KSA directs its efforts towards harmonising the teachings of Islam, along with industrialisation and economic growth, through developing a form of government and a legal system that are able to meet and fulfil modern societal requirements, while also ensuring consistency with the key underpinnings of Sharia. ${ }^{21}$ As such, a number of laws have been enacted, including administrative and commercial laws, and laws in the criminal and labour domains. ${ }^{22}$

With this noted, the traditional subjects of law, namely family law, inheritance, trusts, contracts and criminal law, are all seen to be exclusively defined by the Sharia. Business, labour and broadcasting law, however, are mainly regulated by royal decrees and form part of civil law. ${ }^{23}$ Royal decrees are recognised as one approach to supplementing the Sharia that is in line with modern requirements. Royal decrees adopt the principles of Western legal thought. ${ }^{24}$

Sfeir rightly points out that such statutory enactments have proven successful in supplementing a significant degree of the traditional legal structure without revoking or compromising any of the Sharia's rules. The result is the emergence of a temporal legal sub-system, which is seen to be autonomous but is not entirely independent of the Sharia. ${ }^{25}$ It may be stated that this was an attempt to ease the tension between modernists and traditionalists regarding enacted laws (the impact of traditionalists' approach to enacted law is discussed in the section below). ${ }^{26}$

\section{Components of the System of Government}

Despite the fact that the Basic Law of Governance adopts the form of a constitution, KSA is essentially a non-constitutional monarchy. ${ }^{27}$ Throughout the system, the government is broken down into three branches, executive, legislative and judicial. The executive branch comprises the King, the Council of Ministers and local governments, as well as ministry affiliates and other civic agencies (independent and quasi-independent). The

\footnotetext{
15 ibid 197.

${ }^{16}$ ibid 198.

${ }^{17}$ Hossein Esmaeili, ‘On a Slow Boat Towards the Rule of Law: The Nature of Law in the Saudi Arabia Legal System' (2009) 26 (1) Arizona Journal of International and Comparative Law 1, 6. See also Jennifer Reed and Arthur M Schlesinger, The Saudi Royal Family (Chelsea House 2003).

${ }^{18}$ Basic Law of Governance, Royal Order No. A/91 27 (1 March 1992).

${ }^{19}$ ibid art 1

${ }^{20}$ ibid art 2 .

${ }^{21}$ Bryant W Seaman, 'Islamic Law and Modern Government: Saudi Arabia Supplements the Shari'a to Regulate Development' (1979) 18 Columbia Journal of Transnational Law 413, 414.

${ }^{22}$ Al-Jarbou (n 1) 201.

${ }^{23}$ Hossein Esmaeili and Jeremy Gans 'Islamic Law Across Cultural Borders: The Involvement of Western Nationals in Saudi Murder trials' (1999) 28 (2) Denver Journal of International Law and Policy 145, 147.

${ }^{24}$ Joshua White, 'Mohammed and Madison: A Comparison of the Qur'an and the US Constitution' (2001) 11 (2) Journal of Transnational Law \& Policy 309, 318.

${ }^{25}$ George N Sfeir, 'The Saudi Approach to Law Reform' (1988) 36(4) American Journal of Comparative Law 729.

${ }^{26}$ Al-Jarbou (n 1) 192-200.

${ }^{27}$ The definition of non-constitutional monarchy may be inferred from art 1 of the Basic Law of Governance, which states that the constitution is 'the Book of God'. See for more discussion Tareq Y Ismael and Jacqueline S Ismael, Government And Politics Of The Contemporary Middle East (1st edn, Routledge 2011) 386.
} 
highest executive authority in the state is the Council of Ministers, which is recognised as the main authority over all executive powers. ${ }^{28}$ The King also has legislative power; he is identified as the head of the executive authority with absolute power over it. Notably, all state authorities report to him and view him as the point of reference for all authorities within the state. Accordingly, a supplementary clarification of the executive authority role is detailed and described in the Basic Law. ${ }^{29}$

The authority of legislation in KSA is, to some degree, vague and problematic for outside observers to understand. In contrast to situations in other counties, which are commonly seen to have well-established legislative institutions, KSA has had no legislative body since its founding. The legislative authorities are shared by several governmental institutions. This is due to various political and ideological factors, including the fact that KSA was established based on an alliance between the Al-Saud royal family as the governing party and the ulama religious establishment, which legitimises all the government activities consistent with (or at least not counter to) Sharia. ${ }^{30}$ The Basic Law recognises the ways in which legislative authority handles the preparation of new rules and regulations according to Sharia legislation. ${ }^{31}$ Nonetheless, there are various Saudi legislative bodies, including the King, the Council of Ministers, the Consultative Council 'Majlis Ash-Shura' and the Board of the Senior Council of Ulama. ${ }^{32}$

Finally, the judiciary is considered a key pillar of modern society, with the key purpose of safeguarding the rule of law to guarantee the law is upheld and applied to all people equally. In KSA, the details of the present judicial system are identified in the Judicature Act of 1975 (amended in 2007), with the Act providing for the independence of the judiciary, the structure of the courts and their various jurisdictions and the nomination of judges, their qualifications and immunities. ${ }^{33}$

Article 46 of the Basic Law states that the Judiciary Authority is independent and judges should not be subject to any authority except that afforded by the Sharia. The right of litigation before the courts is, in exactly the same vein, guaranteed to all nationals and residents. ${ }^{34}$ Therefore, the capability for the settlement of disputes is commonly divided in KSA, specifically between various judicial and quasi-judicial bodies. Such bodies are supervised by a number of ministries in line with the disputed subject matter:

i. The judicial bodies: the Sharia court system, under the Ministry of Justice, the High Court, Courts of Appeal and courts of first instance;

ii. The independent judicial authorities: the administrative court system, known as the Board of Grievances (Diwan Almadhalim); ${ }^{35}$

iii. The quasi-judicial committees that work under the supervision of the competent ministry. The major judicial committees are the Committee for the Settlement of Labour Disputes, which run by the Ministry of Labour, and the Customs Committee, which run by the Ministry of Finance. ${ }^{36}$

For the purpose of this paper, the following sections examine the judicial and quasi-judicial body to understand the issue linked to the process of resolving labour disputes and its impact on the rights of TFWs in the absence of a labour court in KSA.

\footnotetext{
${ }^{28}$ Usa International Business Publications (n 6) 44.

${ }^{29}$ Law of the Council of Ministers, Royal Order No. A/13 (27 August 1993), see arts 12 “"The Council of Ministers shall be composed of the following: (a) The President of the Council of Ministers.(b) Deputies of the President of the Council of Ministers. (c) Ministers with Portfolios. (d) Ministers of State appointed as members of the Council of Ministers by Royal Order. (e) Counselors of the King, who are appointed as members of the Council of Ministers by Royal Order." Art 19 (Powers of the Council of Ministers) "Subject to provisions of the Basic Law of Governance and the Shura Council Law, the Council of Ministers shall draw up the internal, external, financial, economic, educational and defense policies as well as the general affairs of the State and shall supervise their implementation. It shall also review the resolutions of the Shura Council. It shall have the executive authority and be the final authority in financial and administrative affairs of all ministries and other government agencies."

${ }^{30}$ Al-Majed (n 11) 216 and 217.

${ }^{31}$ Basic Law of Governance art 67.

32 The Board of Senior ulama was established by Royal Decree No. AI 137 (1971). It is often said that religious scholars (ulama) are well-known in Islamic studies, especially the Board of the Senior Council of Ulama members, usually considered as an advisory body within the Saudi legislative authority. See Sfeir (n 25) 734.

${ }_{33}$ Judicature Act was promulgated by Royal Decree No. M/64 (23 July 1975) and amended on 1 October 2007 by Royal Decree No. M/78.

${ }^{34}$ Basic Law of Governance (n 10) arts 46 and 47.

${ }^{35}$ The Board of Grievances was established in 1955 by Royal Decree No. 2113/8759 and amended on 1 October 2007 by Royal Decree No. $\mathrm{M} / 78$.

${ }^{36}$ Abdulrahman Yahya Baamir, Shari'a Law in Commercial and Banking Arbitration (Ashgate 2010); see also Usa International Business Publications (n 6) 48, 49 .
} 


\section{The Judicial System: Current Reforms}

In October 2007, the late King Abdullah issued a royal decree to reform and modernise the judicial system. ${ }^{37}$ In line with Article 9 of the 2007 judiciary law, the Supreme Court (Almahkama Al'olia) is responsible for taking over the functions of the Supreme Judiciary Council as the highest judicial authority in the Kingdom. ${ }^{38}$

The new Act eliminates the existing Courts of Appeal and founds new Courts of Appeal (Mahkamat Alisti'naaf) in the Kingdom's provinces, which exercise jurisdiction through labour court hearings, criminal circuits, commercial and civil circuits and personal status. Furthermore, Courts of First-Degree (Mahakim Aldaraja Al'oula) are established in areas, regions and centres according to the needs of the system and implement their jurisdiction by specialised criminal, commercial, labour, personal status and general courts. ${ }^{39}$

Banadar Al-Aiban, ${ }^{40}$ in consideration of the court system specifically, states that all the judicial institutions implement wide-ranging structural and organisational developments, including the establishment of a Supreme Court, appellate courts and specialised criminal, commercial, labour, personal status and other courts. ${ }^{41}$

The Sharia courts have general jurisdiction in almost all judicial disputes, but mostly deal with criminal and civil cases. The Supreme Court, Appellate Courts and Courts of First Instance vary in regard to their hierarchal structure and the disputes they preside over. Without doubt, the Supreme Judicial Council is responsible for directing Sharia courts and examining urgent legal cases, as requested by the King or the Minister of Justice. ${ }^{42}$

It is worth emphasising that the labour courts have not yet been established. Until they are, the Primary Commission for the Settlement of Labour Disputes (of the MoL) continues to resolve employment disputes. As detailed by the MoL spokesman, Tayseer Al-Mufrij, the labour court plan has been postponed until 2017, owing to the fact that the legal labour committees and commissions for the court are not yet completely formed. He adds that another reason for postponing the completion of the plan concerns identifying suitable locations for the courts. Once established, the labour courts will be responsible for employers' and employees' complaints such as those related to employment agreement disputes, disagreements about salary, compensation and workplace injuries claims, and disciplinary fines and appeals. ${ }^{43}$

\section{The Board of Grievances (Diwan Almadhalim)}

The second type of court, which is recognised as being entirely independent from the first one, is the administrative court system, known as the Board of Grievances (Diwan Almadhalim), which was established in 1955 and subsequently reconstructed in $1982 .{ }^{44}$ The Board is directly affiliated with the King and is acknowledged as contrasting with the ordinary courts or Sharia court, which has general jurisdiction all over disputes. $^{45}$

In other words, the Board of Grievances comprises a number of civil tribunals, the jurisdictions of which fall outside the system of Sharia courts and its obligations. ${ }^{46}$ The Board of Grievances Law regulates the Board in line with the subsequent hierarchical structure, namely "high administrative court, administrative courts and administrative Courts of Appeal". ${ }^{47}$ Moreover, the missions of the Board of Grievances are centred on analysing administrative decisions, whereby the government and its individual institutions are involved in completing evaluations for the executive of foreign judgments. These evaluations are made to assess the circumstances surrounding the decisions made by bodies that are concerned with government and independent public corporate institutions that follow the government's activities. This facilitates the analysis of cases associated with their rights, as provided for by the pension laws and civil service for government staff and independent public

\footnotetext{
${ }^{37}$ Al-Majed (n 11) 232.

38 Judicature Act (n 33).

${ }^{39}$ While some of the new reforms in the judicial system have still not been introduced, the new judicial structure is presented here.

${ }^{40}$ Banadar Al-Aiban is a president of the Saudi Human rights Commission (SHRC).

${ }^{41}$ This is cited in Thomas W Lippman, Saudi Arabia on the Edge (Potomac Books 2012) 29.

42 Judiciary Act (n 33) arts 6 and 11.

43 Adnan Al-Shabrawi, 'Labor Court Project Postponed to 2017' (Saudi Gazette, $<$ http://www.saudigazette.com.sa/index.cfm?method=home.regcon\&contentid=20150412240052> accessed 9 May 2016.

44 The Board of Grievances (n 35).

${ }^{45}$ Al-Majed (n 11) 228. See also David J. Karl, 'Islamic Law in Saudi Arabia: What Foreign Attorneys Should Know', (1991) 25(1) George Washington Journal of International Law and Economics, 131, 147.

${ }^{46}$ The Commercial Courts have not yet been established. Until they are, the Board of Grievances will continue to exercise first instance jurisdiction over commercial matters.

${ }^{47}$ Board of Grievances Law Art. 8.
} 
institutes. $^{48}$

\section{The Quasi-Judicial Committees}

The quasi-judicial committees are characterised as the third phase of the judicial authority in the country, despite the fact that the Basic Law does not acknowledge such committees as part of the judicial authority owing to the fact that they introduce measures of adjudication via the executive branch. ${ }^{49}$ As mentioned earlier, the Ministry of Justice supervises the Sharia-based judicial system; however, the majority of ministries interpret the rules and laws on matters under their jurisdiction. ${ }^{50}$

These committees are divided into two distinct groups, as discussed, as follows:

i. Committees whose regulations provide for a possible appeal against their decisions to the Board of Grievances. These committees are linked to the Board of Grievances, and examples of such committees are the Committee for Implementing the Sea Ports Code, ${ }^{51}$ the Committee for Controlling Commercial Deception ${ }^{52}$ (formed by the Minister of Commerce) and the Committee for Implementing the Press and Publication Code ${ }^{53}$ (formed by Ministry of Culture and Information) (these committees are outside the scope of this research).

ii. Committees whose regulations provide that their decisions are final. These are independent judicial committees, such as the Commissions for the Settlement of Labour Disputes ${ }^{54}$ (formed by the MoL) and Customs Committees ${ }^{55}$ run by the Ministry of Finance. These committees are introduced by royal decrees, which do not provide that their judgments can be appealed against to the Board of Grievances or to any other judicial body. ${ }^{56}$

Besides such major committees, there are other committees that handle the trials of ministers, and special committees handle military and security personnel within the relevant ministry (e.g. Ministry of Defence). However, all these above committees have appeared mainly with the objective of filling a gap caused by the attitude of the Sharia court on secular legislation and laws originating from the Council of Ministers. ${ }^{57}$ The following section examines the role of the quasi-judicial committees, with specific reference to the Commission for the Settlement of Labour Disputes, to highlight their range of function and to assess its overall effectiveness to solve TFW disputes.

\section{Commission for the Settlement of Labour Disputes}

The SLL created special bodies with the aim of adjudicating disputes between workers (foreign or national workers) and employers in the private sector. ${ }^{58}$ The law identified the authority in charge of issuing the regulations for litigation prior to the commissions. Article 228 of the SLL stipulates that the Council of Ministers is responsible for issuing regulations for litigation before the Commissions for the Settlement of Labour Disputes. $^{59}$

In the absence of labour courts, the SLL refers to these bodies as "Commissions", of which there are two types, the Preliminary Commissions for Settlement of Disputes and the High Commission for Settlement of Disputes. ${ }^{60}$ The law stipulates that

\footnotetext{
${ }^{48}$ Board of Grievances Law Art. 11, 12 and13.

${ }^{49}$ See Al-Majed (n 11) 230; Al-Jarbou (n 1) 224.

${ }^{50}$ Meshal Faraj, Toward New Corporate Governance Standards in the Kingdom of Saudi Arabia (SABIC Chair for IFMS 2014) 40, 41.

${ }^{51}$ Committee for Implementing the Sea Ports Code, Royal Decree No. 27/M dated 24/6/1394H.

${ }^{52}$ Committee for Controlling Commercial Deception, Royal Decree No. 11/9 dated 29/5/1404H.

${ }^{53}$ Committee for Implementing the Press and Publication Code, Royal Decree No. 17/M dated 13/4/1402H.

${ }^{54}$ Commissions for the Settlement of Labour Disputes established in accordance to Art 212 of Labour Law, issued by Royal Decree No. M/51 (27 September 2005), and amended by Royal Decree No. M/24 date 12/05/1434H (24 March 2013) and amended by Royal Decree No. M/64 05/06/1436H (24 October 2015).

${ }^{55}$ Customs Committees, Royal Decree No. 425 dated 5/3/1372H (23/11/1952)

${ }^{56}$ Ahmed Al-Ghadyan, 'The Judiciary in Saudi Arabia' (1998) 13 Arab Law Quarterly 235, 246, 248, 249;

${ }^{57}$ Mohammed h Al-qahtani, 'The Role and Jurisdiction of the Board of Grievances in Saudi Arabia' (PhD Thesis, Newcastle University 2008) 35 .

${ }^{58}$ It is worth highlighting that employee matters in the case of the private sector (national and foreign workers) are controlled by the Ministry of Labour, whereas the Ministry of Civil Services deals with all cases in the public sector, the employees' Civil Services, which are outside the scope of this research.

${ }^{59}$ Labour Law, art 228.

${ }^{60}$ ibid arts 210 .
} 
"each of these Commissions shall solely have exclusive right to consider all disputes relating to this Law and the disputes arising from work contracts. the Commission shall also have the right of access to any premises of the firm for the purpose of conducting the investigation and reviewing all books, records and documents it deems necessary."

Such committees are appointed by the Council of Ministers and administered by the MoL. Pursuant to the SLL, the Preliminary Commissions have been established in offices of the MoL throughout the Kingdom, with the members of the Preliminary Commissions being named from among holders of degrees in Law or Sharia study. ${ }^{62}$

The second commission is the High Commission for Settlement of Disputes, which comprises several circuits, each comprising no less than three members. The law stipulates that "the chairman and members of the commission shall be holders of degrees in Sharia and law, with expertise in labour disputes, and named by a decision of the Council of Ministers, based on nomination by the Minister". ${ }^{63}$

The Preliminary Commission is empowered under law to issue final decisions in labour disputes, irrespective of their type, the value of which should not exceed SR10,000 or approximately USD 2,500. ${ }^{64}$ Such cases should be filed through the competent labour office of the Preliminary Commission in whose locality or under whose jurisdiction the place of work falls. Prior to referring the dispute to the Commission, the labour office must take the necessary measures to settle the dispute through an amicable approach ${ }^{65}$ Should it fail to solve the problem, the office then assists the individual to bring his/her grievance to the Commission.

The Commissions, as tribunals of first instance, also hear cases of disputes over compensation for employment-related injuries, irrespective of the amount of compensation, disputes over termination of service and the imposition of the punishments provided for in law for a violation whose punishment exceeds SR5,000, or violations with a combined punishment exceeding SR5,000. ${ }^{66}$ For labour contract disputes, the law states that no case shall be accepted by the Commissions arising from a work contract after twelve months following termination of the work relation. ${ }^{67}$

Such cases may be taken on appeal to the High Commission, which has the jurisdiction to decide finally and definitively on all appeals brought before it against decisions of the circuits of Preliminary Commissions. ${ }^{68}$

In theory, Saudi Arabia's Labour Commission provides foreign and native workers with an impartial agency to adjudicate and arbitrate labour disputes. However, a large segment of the working residents, domestic or household foreign workers, are excluded from the Commission's jurisdiction. ${ }^{69}$ Furthermore, the Commission's offices are often hard to reach, and such a complaint might need several visits, an expensive and risky proposition for foreign labourers without official documents (passport and iqama), particularly if travelling to another city. ${ }^{70}$ However, the general method for the grievance process is as follows:

i. Filing a grievance together with supporting evidence at the disputes department in the Labour Department;

ii. The Labour Department usually conducts initial investigations and tries to resolve employment issues with the two parties amiably, ${ }^{71}$ then;

iii. If the issue cannot be resolved at this stage, the case is referred to judgment by a Primary Commission;

iv. If either party wishes to appeal against the decision of the Primary Commission, then a submission must be completed to the High Commission within 30 days of the hearing;

\footnotetext{
${ }^{61}$ ibid arts 219 .

62 ibid art 211.

${ }^{63}$ ibid art 215.

${ }^{64}$ ibid art 214.

65 ibid art 220.

${ }^{66}$ ibid art 214.

${ }^{67}$ ibid art 222.

${ }^{68}$ ibid art 216.

${ }^{69}$ These categories are explicitly excluded from the protection of labour laws. In 2013, Saudi government has issued decision No.310 dated 07/09/1434H (15 July 2013) concerning the position of domestic workers.

${ }^{70}$ Human Rights Watch (HRW), 'Bad Dreams: Exploitation and Abuse of Migrant Workers in KSA' (HRW, 2004) 73 - 77 $<$ https://www.hrw.org/reports/2004/saudi0704/> accessed 15 May 2016.

${ }^{71}$ Ministerial Resolution No. 321 (27 November 2013) issued the Executive regulations and rules for an amicable dispute resolution between the two employment parties.
} 
v. The decision of the High Commission is final, obligatory and binding on all parties;

vi. If 30 days lapse and no one from the parties appeals against the Primary Commission's decision, this is standing and enforceable. ${ }^{72}$

\section{Justification of the formation of Labour Dispute Committees}

The current justification behind the formation of administrative committees in general and labour dispute committees in particular consists of two parts: the first is to fill the gap in the specialised judicial functions for specific matters; the second is to speed up and accordingly advance the trials of such cases. However, these justifications might not be deemed adequate deal with the issues caused by the committees concerned. In addition, the earlier analysis of the background circumstances emphasised that the creation of the committees may be attributed to various contradictory reasons. ${ }^{73}$

Many endorse the role of such committees, asserting that they provide a suitable solution for particular needs. Many suggest that these committees have been created on a short-term basis in an effort to deal with new legal issues. $^{74}$ However, given this argument, the term 'temporary nature' does not provide for an exact duration for the work of such committees. Since 2007 there have been serious efforts to reform the judicial authority and specialist courts have been introduced, such as labour courts, to deal with various offences under the King Abdullah Scheme. The effort to reform the judicial system set aside nearly $\$ 2$ billion to build courthouses and train judges in several specialisations outside the Hanbali school of Sharia, as interpreted in the Saudi context, as well as in some specialisations outside the scope of Sharia altogether. ${ }^{75}$

Another justification is that these labour committees are a response to the need for a broad expansion of the social and economic sphere of the country. Also, the Sharia courts are considered incapable of functioning due to their lack of experience of dealing with enacted law. However, some reject this notion, because cases that are adjudicated by these committees can be adjudicated in the Sharia court if the judges are trained and have the appropriate experience. $^{76}$

Another explanation for these committees is that the aim of their creation was to reduce the number of cases coming before Sharia courts. However, one may suggest that this argument is contradicted by the fact that assigning more judges and expanding and establishing more courts under the supervision of the judicial authority might have resolved this issue. ${ }^{77}$

\section{Reviewing the Jurisdiction of Labour Dispute Committee: Legal Inadequacies}

Ruthven argues that foreign workers, especially low-skilled workers, are particularly vulnerable to abuse owing to the fact that employers can use the judicial system against them. ${ }^{78}$ According to a 1996 US Department of State report on Saudi Arabia:

"There have been many reports of workers whose employers have refused to pay several months, or even years, of accumulated salary or other promised benefits. The labour system abets the exploitation of foreign workers because enforcement of work contracts is difficult and generally favours Saudi employers. Labour cases can take many months to reach a final appellate ruling, during which time the employer can prevent foreign labour from leaving the country; alternatively, an employer can delay a case until a worker's funds are exhausted and the worker is forced to retune to his home country."79

That said, assessment of the effectiveness of KSA's Labour Commissions shows that there are several areas of difficulty to be identified. First, in spite of a number of regulations and laws governing the employment relationship and protecting the TFW, these regulations and provisions remain vague and do not provide precise answers to the specific situation of TFWs where there is a conflict with employers under the sponsorship system.

\footnotetext{
72 Abdulmonem Alzalabani, 'Workers' Committees and Employee Voice in Kingdom of Saudi Arabia' (Ilera, 2009) $<$ http://www.ilera-directory.org/15thworldcongress/files/papers/Track_2/Poster/CS1W_4_ALZALABANI.pdf> accessed 7 March 2016.

${ }^{73}$ Hesham Al-Eshaikh, 'Human Rights and the Trial of the Accused: A Legal Comparative Study Between the Judicial System in Saudi Arabia and the Standards Required by the European Convention on Human Rights' (PhD thesis, Newcastle University 2005$) 139$.

${ }^{74}$ Ibid 140. Al-Eshaikh highlights that the Royal Decree No. 63 (22 July 1987) orders the President of the Board of Grievances and Minister of Commerce to investigate the status of the present committees under the Ministry of Commerce, to make a decision to transfer their jurisdiction to be under the Board of Grievances, and to give their suggestions to the Council of Ministers.

${ }^{75}$ Lippman (n 36) 27, 28 and 29.

${ }^{76}$ Ayoub M Al-Jarbou, 'Judicial Independence: Case Study of Saudi Arabia' (2004) 19 (1/4) Arab Law Quarterly 5, 30.

77 ibid 30, 31.

${ }^{78}$ Malise Ruthven, A Fury for God: The Islamist Attack on America (Granta 2002) 145.

79 This report cited in Malise Ruthven, A Fury for God: The Islamist Attack on America (Granta 2002) 145.
} 
It could be said that any employment conflict occurring between the employer and the TFW is expected to affect the TFW's legal status in light of the current kafala system. As a result, many violations are interrelated with employment contract and iqama regulations in such a way that the existing legal structure fails to address TFW issues sufficiently.

The SHRC has criticised the process of resolving labour disputes by the Labour Dispute Commission, which constitutes a violation of human rights in KSA. ${ }^{80}$ As a result of the absence of labour courts, the SHRC identifies the ineffective system of addressing labour disputes as a serious problem facing TFWs. The SHRC highlights key issues faced by TFWs when they submit a case to the commission, including the lengthy process (up to 3 years), a ban on the TFW working with other employers in accordance with SLL Article 39, and the non-appearance of employers at the labour dispute committee. ${ }^{81}$ The labour office seeks the amiable resolution of disputes between parties, which can take up to seven months prior to referring the dispute to the Commission. ${ }^{82}$ Even when the Labour Dispute Commission has issued decisions in TFWs' favour, execution of the judgments has lacked adequate enforcement, such as when employers claim financial difficulties. ${ }^{83}$

The SHRC finds that, in the case of a conflict between a TFW and an employer, the latter can use the power granted by the sponsorship system to report the TFW to the Passport Department as a work runaway, even though the case submitted to the Labour Dispute Commission has not been resolved. ${ }^{84}$ Thus, the grievance procedure has been criticised for not being able to take account of the vulnerability of TFWs and making them vulnerable to economic exploitation because of the lack of implementation of the SLL that would protect their interests, such as transferring the kafala to another employer so that TFWs could earn money and protect the dignity of their labour. ${ }^{85}$

Importantly, the SHRC has also identified the limited jurisdiction of the Labour Dispute Commission in labour cases related to the confiscating of labour passports, ${ }^{86}$ runaway huroob workers,${ }^{87}$ transfer of the kafala and deportation. ${ }^{88}$ Many TFW cases with their employers are interrelated with employment contract and iqama regulations which affect the status of TFWs during the dispute resolution process. The Labour Dispute Committees have decided that issues related to confiscating labour passports, runaway huroob workers and transfer of the kafala do not fall under their jurisdiction, and limit their decisions to employment contract issues such as non-payment of wages. ${ }^{89}$

However, the new Law of the Board of Grievances 2007 has jurisdiction over these committees' decisions. Article 13(b) allows the Board to review decisions issued by quasi-judicial committees ${ }^{90}$ in "cases for revoke of final administrative decisions issued by persons concerned when the appeal is based on grounds of lack of jurisdiction, defect in form or cause, violation of laws and regulations, error in application or interpretation thereof, or abuse of power". ${ }^{91}$ Generally, it is evident that labour dispute mechanisms remain vague in both law and practice, especially in the light of interrelated employment contract and iqama regulations and the lack of jurisdiction.

Second, it is doubtful whether such committees are truly independent; they are mainly administrative bodies, and this vast network effectively exercises regulation with executive authority, undermining judicial independence. ${ }^{92}$

\footnotetext{
${ }^{80}$ Saudi Human Rights Commission Regulation (SHRC) (adopted by Council of Ministers Resolution No. 207 of 12 September 2005).

${ }^{81}$ ibid.

${ }^{82}$ See Ministerial Resolution No. 321 (n 71).

83 This report is highlighted by Alwatan, 'Human Rights Commission Observations on Labour Department' (Alwatan, 2012) $<$ http://alwatan.com.sa/Economy/News_Detail.aspx?ArticleID=125837\&CategoryID=2> accessed 19 November 2016.

84 ibid.

${ }^{85}$ ibid.

${ }^{86}$ The High Commission for Settlement of Labour Disputes, Decision (No 658/2/432) Date 28/06/1432 H.

${ }^{87}$ The High Commission for Settlement of Labour Disputes, Decision (No 1461/1/432) Date 28/06/1432 H; the High Commission for Settlement of Labour Disputes, Decision (No 431/1/60) Date 11/01/1431 H.

${ }^{88}$ The High Commission for Settlement of Labour Disputes, Decision (No 1452/1/432) date 17/11/1432 H; Decision (No 1173/1/432) Date 24/08/1432 H; Decision (No 993/2/432) Date 24/12/1432 H and Decision (No 1317/1/432) Date 07/10/1432 H.

${ }^{89}$ These labour cases have been obtained from the Labour Department without indicating the name of parties, plaintiff (TFW) and defendant (employer). These cases were related to the TFWs from different sectors and different professions. The aim of indicating these cases is to show the impact of the residency regulations on the process of resolving labour disputes, which in turn shows the limited jurisdiction of these commissions in the light of the absence of a labour court in the Saudi judicial system.

${ }^{90}$ Faraj (n 50) 42.

${ }^{91}$ Board of Grievances (n 27) art 13(b).

92 Joseph A Kechichian, Legal and Political Reforms in Saudi Arabia (1st edn, Routledge 2013) 29.
} 
Committees essentially violate the Judiciary Statute, concerning the independence of the judiciary, as stated in Saudi Basic Law Article (46). ${ }^{93}$ The Labour Dispute Settlement Commission is one of these committees that operates under the executive auspices of the $\mathrm{MoL}$ (and ultimately the Minister). ${ }^{94}$ While these committees generally process common violations of workers' contracts, some deal with serious crimes and administer what amount to sentences of fines, imprisonment, deportation, removal and confiscation of business licenses, and bans on recruitment. ${ }^{95}$ Thus, the committees' decisions can amount to extra-judicial sentences that have no legal transparency and only a token process of appeal. ${ }^{96}$ Another hindrance is that the Council of Ministers authorises commissions' litigation regarding settling labour disputes and enabling the committees to usurp judicial (as well as individual) rights. ${ }^{97}$ All judicial and quasi-judicial institutions need to be unified under the auspices of a single central court, which would regulate the interpretation and application of law. ${ }^{98}$

In addition, one of the indirect legal deficiencies of these committees is that they are not established in all cities in Saudi Arabia. Thus, if a case arises in a city or area where the committee concerned does not operate, it might be tried in the conventional Sharia courts, where the judge bases his rulings on fiqh, in contrast to the specific labour laws espoused by the committees. This could lead to inconsistency in judicial rulings and violation of individuals' rights. ${ }^{99}$

Moreover, with regard to the education requirement, Article (31) of the Law of the Judiciary states that the judge must hold a degree from one of the Sharia colleges within KSA. This design has been adopted in an effort to assure that the individual is capable of practising ijtihad (independent reasoning) ${ }^{100}$ According to the interview with former Minister of Justice Dr Muhammad El-Issa, most members of Labour Commission committees are not qualified in the role of judge as per the Law of the Judiciary, simply because the judicial enrolment conditions do not apply to them; it is difficult to transfer them to the general judiciary until judicial cadres are qualified and well trained in labour cases. ${ }^{101}$

Furthermore, another issue associated with dispute resolution includes legal procedures that take a long time to process. Saudi legal experts and economists have called for the establishment of labour courts under the Ministry of Justice to be fostered so that they can deal with urgent worker-related cases. Such calls came after MoL statistics highlighted that only 36 labour dispute cases were resolved on an annual basis, despite there being an overwhelming backlog amounting to 1,400 cases in Jeddah alone. Experts have also suggested stopping the role of the MoL and Labour Dispute Committees because of their failure to resolve disputes relating to employment issues, including unpaid wages, illegal dismissal or violations of workers' rights. ${ }^{102}$ Finally, according to Labour Law, Article 215, the members of these committees must have Sharia or legal (law) qualifications. Article 223 stipulates that

"none of the commissions provided for in this Part shall abstain from rendering its decision on the pretext of the absence of applicable provisions in this Law. In such case, the commissions shall resort to the principles of Shari'ah, established judicial precedents, norms and the principles of justice".

Al-Jarbou argues that the committees should apply Sharia when their own statutes do not have relevant provisions to deal with certain cases. The Islamic Sharia, in such situations, becomes "the default law". ${ }^{103}$ However, this raises the question of whether members of these labour committees with conventional legal

\footnotetext{
${ }^{93}$ See Basic Law of Governance art 46: "The Judiciary is an independent authority. The decisions of judges shall not be subject to any authority other than the authority of the Islamic Sharia."

${ }^{94}$ It is vital to mention that the judiciary system's independence is a critical component in the Saudi Law of Judiciary. This notion proceeds from the Islamic inheritance. Accordingly, the Law of Judiciary (n 25) art 1 stresses that: "Judges are independent and in the administration of justice. They shall be subject to no authority other than the provisions of Sharia and laws in force. No one may interfere with the judiciary."' See, for more details, Richard J Terrill, World Criminal Justice Systems (Lexis Nexis 2009) 586.

${ }^{95}$ Labour Law, chapter XIV.

${ }^{96}$ Rodney Wilson and others, Economic Development in Saudi Arabia (Routledge Curzon 2004) 132.

${ }^{97}$ USA Int'l Business Publications (n 6) 59.

${ }^{98}$ Al-Eshaikh (n 73) 139.

99 ibid 139.

${ }^{100}$ See Judiciary Act (n 33) art 31.

${ }^{101}$ Sabq, 'Labour Courts Obstacles' (Sabq, 2011) <http://sabq.org/FGafde> accessed 4 August 2015.

${ }^{102}$ Arab News, 'Only 36 Labour Dispute Cases Settled a Year' (Arab News, 2014) <http://www.arabnews.com/news/518801> accessed 5 March 2015.

${ }^{103}$ Ayoub Al-Jarbou (n 76) 31.
} 
qualifications are competent to apply and interpret Sharia. ${ }^{104}$

Therefore, it must be concluded that such complex regulation of Labour Dispute Committees under the supervision of MoL is ambiguous and confusing, especially when these administrative bodies are given substantial judicial power that could lead to violation of individuals' rights.

\section{The Negative Role of Traditionalist in Applying Enacted (Labour) Law}

As mentioned, the tension between modernists and traditionalists has led the latter to reject all enacted law, including the SLL. ${ }^{105}$ Although the SLL is an enacted law centred on resolving disputes between the employer and workers (national or foreign), any decisions of the tribunal must conform to Sharia in order to ensure their implementation in KSA. ${ }^{106}$ Nevertheless, it could be stated that nothing regarding complex employment-related issues is identified in the Qur'an; therefore, as highlighted, it is for the relevant competent authority to set and apply these rules and regulations in a way that does not lead to a conflict with the main principles of Sharia. ${ }^{107}$

The Sharia courts are concerned that such legislation may create a conflict with Sharia principles, and thus they refuse to judge cases according to the Labour Law provisions. This is evident from the Sharia courts' passive opposition to the original Labour Law (1969); the Chief Qadi made the following declaration: ${ }^{108}$

"We have been informed that some judges have been in the habit of returning certain cases to the Labour and other offices under the pretext that they fall under the jurisdiction of certain authorities. It is recognized that the Sharia... is completely equipped to solve disputes, to end litigation and to clarify every issue. The submitting of cases to those authorities implies recognition of the man-made laws and the laws repugnant to the provisions of the pure Sharia. It also makes the courts appear incapable. You must look into all cases you receive and make your decisions according to the sublime Sharia. Whenever you have difficulty in doing this, write to us about it."

As a consequence of this circular, the Sharia court was denied the jurisdiction to apply and enforce such laws, which consequently induced the establishment of quasi-judicial committees. It is evident that the main reason for creating the quasi-judicial committees within the Saudi judicial authority is the refusal of several influential religious scholars to adopt and apply regulations within the Sharia court system. ${ }^{110}$ Hence, it is assumed from their resistance and rejection of new laws adopted by the Saudi legislature [at least until the reforms introduced by King Abdullah in 2007 are implemented] that labour cases will continue to be referred to quasi-judicial committees; this compounds the problem of labour issues, already recognised as the most ineffectual aspect of the legislative division of Saudi Arabia. ${ }^{11}$

Al-Jarbou points out that the main objections of the ulama centre on the tenet that God is the only legislator, and accepting man-made law can be considered contradictory to this belief (and the spiritual foundation of Saudi theocracy). ${ }^{12}$ However, as mentioned, Islamic states are entitled to adopt new laws and regulations that do not contradict the principles of Sharia. Furthermore, it is often argued that the Saudi Government does not 'legislate', but 'enacts' administrative regulations under the term 'regulatory authority', in the Basic Law and other laws. ${ }^{113}$

A senior consultant in the Ministry of Justice, Judge Abdulmuhssen Al-Obaikan, emphasises that various efforts have been made by the Ministry of Justice to regulate and restructure the judicial system through the enacting of new laws (i.e. the Law of Criminal Procedure, the Law of Civil Procedure before Sharia Courts and the Code of Law Practice), yet there was opposition from the religious scholars. He adds that "some Islamic religious scholars lack the capacity to be tolerant as they always opt for the extreme and cannot accept moderation". ${ }^{114}$

\footnotetext{
${ }^{104}$ Ibid 51; Al-Jarbou (n 1)197.

${ }^{105}$ Al-Jarbou (1) 205.

${ }^{106}$ Maren Hanson, ‘The Influence of French Law on the Legal Development of Saudi Arabia' (1987) 2(3) Arab Law Quarterly 272, 289.

${ }^{107}$ It is often said that Sharia principles come from a 1,400-year-old religion which did not set detailed rules and regulations for future developments.

${ }^{108}$ Al-Jarbou (n 1) 202 and 203. The term Qadi is referred to (the Chief Judge).

109 Cited in al-Jarbou (n 1), 'Circular of the Presidency of the Judiciary 25 (the Chief Judge)' numbered 1849/3/M, on AH 14/6/1385.

${ }^{110}$ Ayoub Al-Jarbou (n 76) P 24. See Circular 1849/3/M. Ministry of Justice. See also Al-qahtani (n 57) 36.

${ }^{111}$ Ibid, see more discussion Joseph Kechichian, 'The Role of the Ulama in the Politics of an Islamic State: The Case of Saudi Arabia' (1986) 18

(1) International Journal of Middle East Studies 53.

112 Al-Jarbou (n 1) 201, 202.

113 ibid.

114 Sheikh Abdulmuhssen Obeikan, 'The Codification of Islamic Sharia - Asharq Al-Awsat' (Asharq Al-Awsat, 2006) $<$ http://www.aawsat.net/2006/04/article55266913/the-codification-of-islamic-sharia> accessed 19 April 2016.
} 
The ulama believe that labour regulations may be a preliminary step to codifying the Sharia, ${ }^{115}$ which could ultimately replace the latter with positive law. ${ }^{116}$ Thus, the codification would make Islamic laws provisions, amendable by the legislative power, as has occurred in many Islamic countries. However, Sheikh Al-Obaikan supports the idea of codifying Sharia and expresses his argument by saying:

"Why would this be religiously prohibited? What is the difference between the books of jurisprudence and the codification of the rules? We know that books of jurisprudence contain rules directly or indirectly taken from Qur'an and Sunnah to make it easier to teach students and to facilitate legislation. Codification and the books of jurisprudence are the same."117

It is worth noting that since the establishment of the KSA in 1932, efforts have been made to codify the Sharia rules; however, these have proved unsuccessful. There was significant resistance from the senior Saudi religious scholars, which was so strong that policy-makers were unable to face the challenge. ${ }^{118}$ However, it could be argued that the reason for the rejection of the application of such enacted laws by the Sharia courts is that Sharia court judges do not have legal training, as their qualifications are in Sharia. ${ }^{119}$

Al-Eshaikh points out the difference between judges on the Board of Grievances and those in the Sharia courts. Despite the fact that both types of judges have completed their study in Sharia, judges on the Board of Grievances adopt and apply enacted law because many of them have received intensive legal training at the Institute of Public Administration. In practical terms, traditionalist rejection of laws that do not essentially contradict Islamic law, such as the Labour Law, led to the abolishing of their jurisdiction (as a judicial authority) from a substantial number of cases related to employment issues, which forced the government to transfer the cases to administrative committees that are under executive authority. ${ }^{120}$

\section{Recommended Resolution}

Upon completion of a review of the current legal system of Saudi Arabia highlighting its key features and institutions, it is clear that there are overlaps between the state authorities, especially concerning the duality of its judicial system, which certainly creates conflict and ambiguity. ${ }^{121}$ This relates to various factors, which have collectively caused conditions of disorder and confusion in the current Saudi legal system, creating legal deficiency and vagueness not only for foreign workers but even for Saudi nationals.

Al-Majed tries to provide suggestions to override the legal deficiencies within the Saudi legal system by calling to unify the legislative body, because the legislative authorities are dispersed across institutions. ${ }^{122}$ A legislative body should have exclusive power to enact new laws and regulations and take responsibility for any conflicts that may occur between the bodies of legislative authority. ${ }^{123}$ Furthermore, it should implement wide-ranging reform, with the aim of reviewing the fundamentals of the legal structure. ${ }^{124}$ This has to include reforming the authorities and responsibilities related to the executive, legislative and judicial bodies in the country. Such reforms can be implemented by identifying the jurisdictional overlaps between the state's authorities, with special reference to the judicial authority, and providing more authority to the Consultative Council (Majlis al-Shura) to make it a fully legislative body. ${ }^{125} \mathrm{Al}-$ Khanezan stresses that the quasi-judicial committees must form a

"unified regulatory body to enhance independence, and should be considered responsible for the general jurisdiction over all disputes that arise between individuals or legal persons. These suggestions come in

\footnotetext{
${ }^{115}$ Al-Jarbou (n 1) 206

${ }^{116}$ According to a leading scholar of Islamic law, “Abou el Fadl's, 'classical Islamic law' has always resisted codification and encouraged interpretation through ijtihad. In fact, he argues that such uniformity through codification contradicts the very nature of Islamic law." cited in Elyse Semerdjian, Off the Straight Path (Syracuse University Press 2008) 3.

${ }^{117}$ Cited in Torki A Alshubaiki, 'Developing the Legal Environment for Business in the Kingdom of Saudi Arabia: Comments and Suggestions' (2013) 27(4) Arab Law Quarterly 371, 384-385.

118 ibid

119 Al-Majed (n 11) 195, 198; Al-Jarbou (n 1) 194.

${ }^{120}$ Al-Eshaikh (n 73) 145.

${ }^{121}$ See above Al-Majed (n 11) 232.

122 Ibid 233-237.

${ }^{123}$ As discussed, the legislative authorities are dispersed across institutions; the King, the Council of Ministers, the Supreme Judicial Council and the Consultative Council are all considered as adopting legislative jurisdiction.

${ }^{124}$ The new Judicature Act promulgated in 2007 was certainly a remarkable step (even though it is still not completed) in the right direction; it would allow more in-depth alterations in the system.

${ }^{125}$ Al-Majed (n 11) 233-237.
} 
line with current reforms of the Saudi legal system issued by Royal Decree No. M/79 in 19/09/1428H, to reform the judicial branch by establishing new courts such as Labour Court and Commercial Court." 126

However, these reforms have still not been implemented. Al-Eshaikh suggests that if the existence of these committees (such as Labour Disputes Committees) continues, a single law should be devised to regulate the jurisdiction and procedures of all committees, with their rulings being subject to the Board of Grievances (and not the Scrutinizing Committee, which does not provide assurance of fair trial). ${ }^{127}$ All decisions made by these committees should be reviewable; according to Article 8/B/2 of the Board's Law of the Board of Grievances, because of the lack of jurisdiction of committees or the need for general appeals against decisions because of the inadequacy of the proceedings, verdicts of committees must be appealable; otherwise, the committees cannot be justified within the legal system. ${ }^{128}$

In consideration of the resistance of the traditional Islamic scholars, Al-Jarbou suggests that in order to achieve harmony between traditionalist approaches and contemporary demands, the first step towards ending the traditionalists' reluctance to apply and enforce the enacted laws can be achieved by asking the Board of Senior Ulema to give opinions on such law. ${ }^{129}$ The Board's opinions should clarify whether the enacted laws are in the interests of the country, allowing people's affairs to be organised without contradicting Sharia. The second step related to ending traditionalists' hesitancy is to agree that all drafted laws must be examined by the Board of Senior Ulema before they are enacted, to ensure that no law contains provisions contradicting the Sharia. As a consequence, the Board should be part of the legislative process, at least as an advisory body. ${ }^{130}$ The third step is to provide compulsory legal training and seminars for all judges, especially those with Sharia qualifications. ${ }^{131}$

Finally, the issue of law has to be addressed from a different perspective than the religious one. Several ulama recognise the importance of codifying the Sharia. ${ }^{132}$ For instance, Sheikh Al-Obaikan expresses his interest in codification by stating:

"The human mind is limited, which may cause conflict between opinions. It is for this reason that codification is necessary. It would contribute to establishing justice. It will facilitate a judge's work and relieve him of conducting difficult research in the books of jurisprudence. We are living in times that require rapid verdicts in accumulating cases. This process will be speeded up by codification. Codification would also be useful to end the serious matter of conflicting verdicts that sometimes occur within the same case and in the same city, perhaps even in the same court or that are issued by the same judge." 133

\section{Conclusion}

This article has examined the Saudi legal system in an effort to provide answers to the research question concerning the way in which the Saudi legal system is applied to protect TFWs in the case of employment conflicts and exploitation. Particular information regarding the Saudi legal system has been given, and the extraordinary influence of Sharia on the legal system has been mentioned. Specifically, the Basic Law and the executive, legislative and judicial authorities have been analysed in order to guide the understanding of issues linked to the Saudi judicial system.

Due to the absence of a labour court in the current judicial structure, the commissions for the settlement of labour disputes play a significant role in adjudicating and resolving disputes related to employment agreements. Even though the regulations for litigation before the Commissions for Settlement of Labour Disputes are issued by the executive authority, which is not recognised by the Basic Law as a part of the judicial authority, they still enjoy a major role in providing administrative justice to ensure that the bulk of citizens and TFWs access justice. However, the regulations for litigation before these committees show that there are legal deficiencies in the

\footnotetext{
${ }^{126}$ Mansour Al-khnezan, 'Quasi-judicial Committees: The Problem and Solutions' (2011) <http://www.alriyadh.com/639561> accessed 3 March 2015.

127 Al-Eshaikh (n 73) 145 and 146.

128 Al-Jarbou (n 1) 229.

129 ibid 226 and 229.

130 ibid.

${ }^{131}$ It is worth mentioning that the King Abdullah scheme 'Educational Branch' has sent many Sharia jurists to study out of the country. This was assumed to be helpful to allow them to form a view on the new legal reforms adopted globally.

132 Alshubaiki (n 117) 384.

133 Obeikan (n 114).
} 
existing rules, which may affect the rights of both foreign and Saudi workers in the case of employment disputes.

For this reason, it is vital to review the commission's jurisdiction and examine the decisions of the committees in TFW cases relating to employment contracts and residency regulations in light of the kafala system. As explained, many violations are interrelated with employment contract and residency regulations in such a way that the existing legal structure fails to address TFW issues sufficiently. This paper has identified the limited jurisdiction of the Labour Dispute Commission in labour cases related to the issues such as confiscating of labour passports, runaway huroob workers and transferring the kafala. This indicates the overlapping jurisdiction between passport and labour regulations in such cases. These regulations do not prevent the employer from abusing the sponsorship system by using the power granted to him by such a kafala system.

Furthermore, it is evident from the discussion that labour dispute mechanisms remain vague in both law and practice, especially in the absence of free legal aid. The current mechanism fails to take into consideration the socio-economic backgrounds of TFWs. As explained, the majority of workers are recruited from the most vulnerable and marginalised groups in society from various countries and speak different languages. This study argues that the current restrictive legal framework governing the employment of TFWs simply does not treat TFWs as rights-holders. Thus, these factors undermine TFWs' capability to enjoy their rights or access justice when exploitation occurs. Therefore, this study argues that Saudi authorities are accountable for protecting and fulfilling TFW rights.

One may suggest that the commission's jurisdiction should be amended to cover issues related to residency regulations that interrelate with employment contracts, such as renewing work and residency permits and reporting runaway worker cases. Such major reforms need to be implemented by unifying the judicial structure rather than establishing quasi-judicial committees in order to enforce enacted laws as well as codify the rules of Sharia and to promote consistency in court decisions. This also requires the establishment of new secular courts constituted by and operating under the Ministry of Justice, such as labour courts, to eliminate all kinds of uncertainty and ambiguity in the structure and jurisdiction of the judicial system. 